cancer parasite is at the best doubtful, the existence of the parasite, cancer, is beyond a doubt. ...... The cancer cell is in itself a parasite, and is endowed with that formidable attribute of the more highly pathogenic parasites-the attribute of infectivity." I then pointed out that, although cancer is an "infective" disease, it is probably not "infectious." I went on to show that a due appreciation of the "infective" nature of cancer tends, not to confuse, but to coördinate certain phenomena of tumour-growth, such as relative malignancy, which otherwise are hard to apprehend. I am, Sir, yours faithfully,

University of Sydney, Jan. 15th, 1912. D. A. WELSH.

\section{THE CRESCENDO MURMUR OF MITRAL STENOSIS.}

To the Editor of THE LANCET.

SIR,-I beg to thank you for your very appreciative and much appreciated review of my small work on the elements of cardiac auscultation which appeared in THE LANCET of Jan. 27th. In this review you say that "the view that the crescendo murmur of mitral stenosis is ventricular systolic and not auricular systolic is, we believe, gradually gaining ground, but it is not as yet generally adopted." May I direct the attention of your readers interested in the subject to a paper by Weiss and Joachim, of Königsberg University, published in the Zeitsohrift für Klinische Medioin, 1910, Vol. XIII.? These observers have done me the honour of devoting five of the eighteen pages of their article (The Registration of the Heart Sounds and Murmurs by Means of the Phonoscope, and their Relation to the Electro-cardiogram) to testing my theory on the causation of the crescendo murmur. They have taken tracings of the heart sounds and murmurs of mitral stenosis by means of the phonoscope synchronously with tracings of the movements of the auricle and ventricle with the string galvanometer. The evidence thus gained on the point at issue is therefore absolutely reliable. In their paper they say that if my theory is correct two things must happen: (1) The first sound in mitral stenosis must be abnormally delayed; and (2) the commencement of the crescendo murmur must be at a point of time at which the commencement of ventricular systole may be assumed.

These conditions are quite fair. As to the first point, they say that in 17 out of 18 cases of pure mitral stenosis the first sound was definitely late; and as to the second, they conclude that " the terminal portion of the crescendo murmur -namely, that portion which immediately precedes the first heart sound - is of ventricular origin, that is protosystolic." Dr. Joachim in a private letter says that he agrees with my contention as to the causation of this terminal part of the crescendo murmur, which he calls protosystolic in rhythm, and I call early ventricular systolic or presphygmic. I have always limited my argument to that part of the so-called presystolic murmur of mitral stenosis, which is of crescendo force and rising pitch, and this only occurs immediately before the first sound by which it is abruptly terminated. Murmurs of increasing force unless accompanied by rising pitch are not the true so-called crescendo murmurs. I may also state that papers by other writers are being published from time to time in which a true crescendo murmur is heard, but there is no evidence of auricular systole-i.e., as judged by electro-cardiograph tracings (e.g., on the Mechanism of the Presystolic Murmur, T. Stuart Hart, Medioal Record, July Ist, 1911).

I am, Sir, yours faithfully,

Manchester.

E. M. BRockBANK, M.D. Vict., F.R.C.P. Lond.

\section{THE PATHOLOGY AND TREATMENT OF EXOPHTHALMIC GOITRE.}

To the Editor of THE LANOET.

SIR,-I am much interested in Dr. G. R. Murray's paper in THE LANCET of Feb. 24th on the above subject. He mentions a case that had 11 doses of $X$ rays in about five weeks from Nov. 28th, 1911, to Jan. 5th, 1912. The right lobe of the thyroid vas removed on Jan. 9th, and he states that now the pulse-rate varies from 92 to 120 , whereas, before the operation, it varied from 120 to 204 . I would like to suggest that the good result is largely due to the application of the rays rather than to the operation.
Since 1905 I have treated 31 cases of Graves's disease with $X$ rays alone in private and in hospital practice. Of the 14 private cases 10 are cured and the remaining 4 practically well. Of the 17 hospital cases 7 are cured, 4 are markedly relieved, 4 show very little relief, 1 was operated on with a fatal result after five applications, and 1 has only started treatment. Altogether, therefore, the cured and greatly relieved number over 80 per cent. I claim that no other method of treatment, surgical or otherwise, can show such good results in this most intractable of diseases.

Here in Leeds we are coming to the conclusion that the $X$ rays is, so far, the only rational and scientific mode of treatment.

I am also interested in the microscopical findings of the lobe of the thyroid that had been exposed to the rays. If it had been removed later these changes would have been more marked.--I am, Sir, yours faithfully,

LEO A. ROWDEN, M.B., C.M.,

Feb. 25th, 1912 Honorary Director, Flectro-Therapeutic Department,

WEEKLY PAYMENTS AT ST. BARTHOLOMEW'S HOSPITAL: A CORRECTION.

To the Editor of THE LANCET.

SIR,-Considerable inconvenience has been caused by a statement which appeared in the press on Feb. 22nd, implying that St. Bartholomew's Hospital is offering treatment "for a weekly payment of £2."

I wish to say that no such offer has been made, nor has there at any time been a suggestion of making an offer of the kind. The statement is therefore entirely without foundation so far this hospital is concerned, and I can only assume it was made under a misapprehension.

Feb. 24th, 1912 I am, Sir, yours faithfully, Thomas HaYes, Clerk.

\section{UNICELLULA CANCRI.}

\section{To the Editor of THF $\mathrm{TANCET}$}

SIR, - I have only recently read the very interesting lectures on Unicellula Cancri delivered by the late Sir Henry Butlin before the Royal College of Surgeons. and reported in THE LANCE'T of Nov. 25th and Dec. 2nd, 1911. An explanation of the facts put forward occurred to me some three or four years ago. It is that cancer and sarcoma (and also some of the benign growths) are due to, not a symbiotic association of a parasite and a tissue cell, but to a sort of "fertilisation " of a tissue cell by a parasite of a protozoan nature. The result is, as is said in the lectures, that a new " animal " is produced which is similar to the original cell in nature and growth in many respects, and yet, so to speak, has a strange new vitality. As the tissue cell before the process which I call "fertilisation" takes place was a specialised cell, so the new growth is a multiplication of that cell, and of that kind of cell only.

The chief facts in support (other than those put forward in the lectures) are three in number. 1. The workers at the Cancer Research Laboratories have shown that the cells in a beginning cancer and in the edge of a growing tumour behave for several generations like germinal cells undergoing maturation, as judged by the karyokinetic figures observed. 2. They have also shown that the blending of "white blood corpuscles" (really, in my opinion, amceboid parasites) with tissue cells can sometimes be observed in very young growtbs (but I understand not in metastases). 3. By other observers working with mice tumours it has now been conclusively proved that sometimes a carcinomatous transplantation has suddenly taken on sarcomatous characters. This last is easily understandable if we assume that under the conditions of the experiment (perhaps simulating the natural conditions suitable to the growth of débris from a naturally sloughing tumour which has naturally become lodged in a susceptible host) the reverse of the "fertilisation" sometimes occurs and the parasite itself is regenerated in a form able to attack any cell handy to it in its new host and by a new "fertilisation" sets up a new type of growth, and, if the cell of the host attacked happens to be a connective tissue cell, a sarcoma results.

According to this view there are possibly two species of parasite. One only endows the cell it fertilises wiuh powers 